\title{
Income Tax Dispute Settlement With Justice Perspective
}

\author{
Sonny, SE., BKP \\ Institut STIAMI \\ stellayoung1881@yahoo.com \\ DOI: 10.29322/IJSRP.11.07.2021.p11576 \\ http://dx.doi.org/10.29322/IJSRP.11.07.2021.p11576
}

\begin{abstract}
A material dispute or commonly referred to as a material dispute occurs when there is a difference in the amount of tax owed or a difference in the amount of excess tax according to the tax authorities listed in the tax assessment, with the amount according to the calculation of the taxpayer. These differences of opinion may involve differences of opinion regarding the legal basis that should be used, different perceptions regarding a tax regulation provision, and a dispute or a certain transaction or it could be due to other reasons. All of these, can result in the amount of tax determined by the tax authorities to be different from the amount according to the calculation of the tax authorities with the taxpayer which is a material dispute. The research specifications in this study were carried out by means of a normative juridical approach, namely testing and reviewing secondary data. With regard to the normative juridical approach used, the research was carried out through two stages, namely library research and field research which was only supporting, the data analysis used was qualitative juridical analysis, namely the data obtained, then compiled in a systematic, comprehensive and integrated manner to achieve clarity of the problem to be discussed. The result of this study is that the tax dispute resolution procedure can only be resolved through the tax court, considering that the tax court is an instrument that can be used as a means for justice seekers to obtain justice. Tax dispute is a dispute that arises in the field of taxation between the taxpayer and the tax authorities as a result of the issuance of a decision that can be appealed or sued to the tax court based on the tax laws and regulations.
\end{abstract}

Keywords: Principles of Justice, Tax Dispute Resolution, Indonesian Tax Law

\section{INTRODUCTION}

Although taxes are not the only factor driving interest in investment, 1 but the tax system that applies in a country is a consideration for investors to choose which country to invest in. The imposition of relatively small taxes or tax exemptions in a country (tax haven) is attractive to investors because it has become a symptom of society in any country that people tend to pay relatively small taxes, even evade or avoid taxes. Such an action will clearly harm state revenues from the tax sector (tax loss).

The causes of tax losses (tax loss), can occur for various reasons, namely:

1. Legislation. In this case the laws and regulations provide exceptions or deductions in the context of incentives to taxpayers. These laws and regulations can be found in the Income Tax Law, the PBB Law, the PMA/PMDN Law and various Government Regulations that provide tax incentives.

2. Tax losses arise due to the actions or actions of the taxpayer himself. In this act, it can be divided into tax avoidance, namely tax evasion that does not conflict with the law and tax evasion or tax dodging, namely tax evasion that is contrary to the law (tax smuggling). Included in this category, for example, taxpayers do not report all income subject to tax, increase the cost of goods and lower the selling price.

3. Tax losses caused by tax officials (fiskus), such as corruption or cooperation between the tax authorities and taxpayers.

Taxpayer forms and losses that result in losses in the tax sector include:

1. the taxpayer does not pay taxes correctly, in other words, does not report all the income he receives which according to the legislation is an object of tax.

2. economic activities carried out by taxpayers "hidden" with the intention of avoiding tax payments (underground economy = underground economy), including illegal logging, illegal fishing, illegal mining, commercial sex workers (PSK) and so on.

3. Taxpayers invest abroad (capital flight) with considerations that are more profitable than domestic ones. The benefits in question can be in the form of more guaranteed confidentiality or a more profitable tax system abroad, such as lower rates and so on.

In order to attract investors, various facilities have been provided which are much wider than the facilities or incentives provided in Law no. 11 of 1970 and Law no. 12 of 1970. The facilities provided by Law no. 25 of 2007, among others, covers the fields of:

a. Taxation, in the form of reduction of net income in the context of Income Tax $(\mathrm{PPh})$, exemption or relief from import duty on imports of capital goods, exemption or deferral of VAT on imports of capital goods/machinery, accelerated depreciation or amortization and relief from PBB. 
b. The ease of obtaining land rights and the length of time of ownership of land rights, which are deviations from the provisions of the UUPA.

c. Immigration services are in the form of granting a limited stay permit to foreign investors for 2 years, after which a permanent permit can be obtained.

d. Employment

With Law No. 25 of 2007 there are additional investment facilities in the field of immigration, which was not previously regulated in Law No. 1 of 1967 Jo. Law No. 11 of 1970. Likewise, the tenure of land rights in the form of HGU, HGB and Hak Use is longer than that specified in the UUPA. Regarding the tax holiday, it is not regulated in Law no. 25 of 2007 as implemented by Law no. 1 of 1967 Jo. Law No. 11 of 1970 on PMA.

Tax amnesty is not granted to taxpayers who are in the process of being audited for tax purposes or in the process of being investigated (Article 8 of Presidential Decree No. 26 of 1984). Taking into account the formulation of Article 8 of the Presidential Decree, there are two indicators/criteria that are regulated, namely regarding subjects who are granted tax amnesty and criteria for tax violations.

Regarding the subject to which the tax amnesty is granted is the taxpayer who, at the time of the enactment of the Presidential Decree. No. 26 of 1984, is not currently under investigation or investigation. This situation will certainly give a sense of injustice to taxpayers who are under examination or investigation, considering that tax amnesty is only given to taxpayers who "coincidentally" are not in the process of examination and investigation or have not been examined or investigated.

Regarding the criteria for tax violations, in the event that the taxpayer commits an administrative violation such as not submitting an SPT, not carrying out tax obligations in accordance with laws and regulations, and so on, but not yet carrying out the examination process, then the taxpayer can be granted tax amnesty. in accordance with the provisions of Article 7 paragraph (1), namely no fiscal investigation is carried out. This is different from taxpayers who are in the process of being investigated.

Taxes play an important role in development because of the two functions attached to it, namely the budgetary function and the regularend function. The function of the tax budgeter is to fill the state treasury in order to launch the wheels of government by collecting as much money as possible in accordance with applicable laws which in time will be used to finance state expenditures, namely routine expenditures and development expenditures, and if there is any remaining surplus) will be used as Government savings. While the regularend function is a function that can be utilized by the Government to support the Government's efforts in the economic, social, and cultural fields according to what has been stipulated in the development program (Boediono, B. 1996:11). This includes regulating or implementing policies in the social and economic fields. In addition, taxes play an important role because of their very dominant contribution in supporting the State Revenue and Expenditure Budget (APBN) (Tjip Ismail. 2010: 275-276).

Tax is one of the sources of state revenue which is very important for the administration of the Government and the implementation of national development. The importance and strategic role of the taxation sector in the administration of the Government (Wirawan B. Ilyas and Richard Burton. 2008: 11). The legal relationship in the imposition of this tax becomes clear that the notion (ratio) of collection carried out based on the law is the transfer of wealth regulated by counter-achievement. indirectly, because the form of contra-achievement obtained by the community is indirectly in the form of public goods and services organized by the government in the context of a welfare state (Agus Surono. 2013:5).

Taxes are positioned as the backbone of development revenue. The implication is that taxes are still often perceived as a burden, so people are reluctant to pay taxes (Burkens, M.C. 1990: 29). The increase in the target and realization of tax revenue each year is based on several reasons, namely: 1) to offset the diminishing role of foreign debt as a source of development financing; 2) to suppress the tendency of the Indonesian economy to heat up more and more. This can be seen from the inflation rate in recent years which has averaged above nine percent; and 3) To minimize opportunities for tax evasion and evasion (Revrisond Baswir. 1997:107).

\section{LITERATURE REVIEW}

\section{Justice in Tax Debt Exemption}

Justice is one of the necessities of human life that is absolute in any place and situation in the world, although the concept and content will vary according to the values believed in certain community groups. Therefore, the concept and definition of justice is very diverse. By citing the opinions of various figures, Soetjipto Rahardjo has made an inventory of 9 formulations of justice as follows:

1. give everyone what is due;

2. give to every person according to the law to be entitled;

3. a policy of giving everyone a share of the proceeds;

4. the freedom of people to do anything as long as it does not violate the freedom of others;

5. provide for the satisfaction of everyone's needs;

6. the personal equality of all ;

7. the freedom of everyone to pursue prosperity;

8. providing opportunities for everyone to seek the truth;

9. freedom to develop interests in an equal position

With such diverse understandings of justice, the analysis of tax amnesty will be more focused on the legal aspect, because justice is one of the basic legal values in addition to the usefulness and certainty of Hadi, H. (2017). Thus justice in law is not just rights and obligations as determined or ordered by law, justice that stands alone apart from other basic values. Likewise, it cannot be measured in the concept of justice known in the tax literature, namely vertical justice and horizontal justice, which produces 
progressive rates solely as a manifestation of the principle that the greater the ability or carrying capacity of a person, the greater the tax that must be paid.

At the beginning, it was stated that the theory of tax collection may only be appropriate and applicable in a state concept, the conception of society and the conception of a certain legal philosophy. Therefore, the consideration of tax theory is ultimately a legal issue that has a value dimension. Based on the legal basis above, tax amnesty in the perspective of justice must also pay attention to the values of certainty and benefit.

The need for justice will never stop, regardless of ethnicity, nation, culture, region, religion and so on, especially demands in the context of taxes considering that tax payments do not recognize direct contra-achievements that can be accepted by taxpayers. The issue of fairness in tax amnesty arises when tax amnesty is not given to all taxpayers but is limited to taxpayers who have violated or disobeyed their tax obligations. With tax amnesty, the tax debt that previously had to be paid is canceled, in other words, the amnesty results in the elimination of the obligation to pay the previously owed tax.

Considering that tax debt is an engagement (which arises because of the law), the abolition of the obligation to pay debts (taxes) must be reviewed from the concept of civil law. Article 1381 of the Civil Code stipulates 10 (ten) ways to terminate the engagement, namely payment, offer of cash payment followed by deposit or custody, debt renewal (novation), debt settlement (compensation), mixing debt, debt relief, destruction of goods owed, cancellation or cancellation, application of a condition of cancellation and expiration.

Of the ten methods of annulment of engagements above, there is no/unknown mention of the method of amnesty, moreover the elimination of tax debts through this amnesty is regulated or stipulated in a Presidential Decree (No. 26/1984). It must be admitted that debt (tax) is basically subject to the rules of civil law, but considering that tax is a state monopoly right, tax debt has aspects of public law (state administration). In the relationship between civil law and public law (state administration), according to Paul Scholten there is a relationship between general law and special law so that the lex specialis derogat lex generalis principle applies. This principle places Civil Law as general law and Administrative Law (tax law) as special law Supriyadi, S., Setiawan, B., \& Bintang, R. M. (2018).

The Civil Code does not provide an understanding or definition of what is meant by debt relief. Mariam Darus Badrulzaman provides an understanding that debt relief is an act or statement of the will of the creditor to free the debtor from the engagement and the statement of will is accepted by the debtor Maheswara, RH (2020). Meanwhile, according to R. Setiawan, debt relief is a legal act in which the creditor relinquishes his rights. to collect his receivables from the debtor Maheswara, RH (2020).

The existence of a statement of will from the debtor shows that the engagement that arises because of an agreement in civil law, is a reciprocal legal relationship, meaning that the creditor and debtor parties have their respective rights and obligations. Therefore, the agreement of the parties is a valid condition of the agreement (Article 1320 of the Civil Code). This is different from the tax engagement, which arises because of the law so that the agreement as a condition of the agreement does not apply to the tax (engagement).

As a consequence, the tax exemption (debt) resulting in the abolition of the engagement does not require the approval of the taxpayer. Thus, the exemption of tax debt (principal) as a result of tax amnesty can be carried out unilaterally by the state, or in other words the right of the state as a creditor to collect taxes can be released without having to get approval from the taxpayer. The unilateral statement of exemption from tax debt must be stated in the Tax Amnesty Act. In the Presidential Decree. No. 26 of 1984 and Pen.Pres. No. 5 of 1964, the statement was not formulated explicitly, especially because the two regulations do not provide an understanding or definition of the tax amnesty itself.

The Indonesian state in protecting and regulating its citizens must carry out its functions properly. In carrying out its functions, the government or local authorities need funds. One of the funds needed as a source of revenue used to finance these expenditures comes from levies in the form of taxes from the people.

Collecting taxes as one of the obligations of citizens, and as one of the collection of funds to carry out the economic functions of developing countries dynamically from year to year in each country. (Siti Kurnia Rahayu, 2017: 8-9).

In addition, taxes are levied with the aim of financing the procurement of public goods, but taxes can also be levied to achieve certain goals set by the government, including the functions of allocation, distribution and stabilization. The use of taxes to carry out state (government) functions should adhere to the principles of good governance, namely law enforcement, transparency, accountability, efficiency, professionalism and involving broad community participation. (Haula Rosdiana and Edi Slamet Irianto, 2012:26)

Currently, the types of central taxes managed by the Directorate General of Taxes include: Income Tax (PPh), Value Added Tax (PPN), Sales Tax on Luxury Goods (PPnBM), Land and Building Tax (PBB), and Stamp Duty. In addition to these types of taxes, there are also taxes levied by local governments, namely Motor Vehicle Tax, Motor Vehicle Transfer Fee, Motor Vehicle Fuel Tax, and others. (Mardiasmo, 2011:11-13)

At the same time, it is also known that the main source of state revenue comes from a predetermined tax system. In the sense that the source of state revenue in the form of taxes continues to be improved in supporting the development process, which is carried out in accordance with its own capabilities based on the principle of independence.

To achieve this, an awareness in the field of taxation is needed, namely with public awareness so that they can play an active role in fulfilling their obligations as taxpayers. This is intended, because through public awareness in the field of taxation, it will result in an increase in the amount of tax payments in an understanding that leads to an increasing obligation to implement tax laws and regulations. As a consequence, the number of potential tax disputes that occur is increasing.

It is known that tax collection in Indonesia refers to a self-assessment system. Self-assessment system is a tax collection system that gives authority, trust, and responsibility to taxpayers to calculate, calculate, pay, and self-report the amount of tax that must be paid. (Anastasia Diana and Lilis Setiawati, 2014: 1). 
In accordance with the description above, it is necessary to have a judicial institution with a law that can guarantee the rights and obligations of taxpayers in accordance with the Taxation Law, so that they can give/impress judges' decisions on tax disputes with a simpler process, fast and cheap. Thus the decision of the tax judiciary can be used as a guide in implementing the tax law properly in accordance with the applicable tax provisions in order to create legal certainty for all parties as taxpayers.

Since the tax dispute resolution process that has been outlined in the Taxation Law, namely the General Provisions and Tax Procedures, which contains the main provisions concerning the Tax Procedures, it also contains the main provisions regarding the Tax Courts Agency, the preparation of a law If the law contains a tax justice system, the mechanism in the tax dispute resolution process must go through the Tax Dispute Settlement Agency. The decision of the tax court institution is a guide and reference in implementing the tax law so that the tax law can provide legal certainty. Therefore, with this law, a Tax Dispute Settlement Agency is established whose direction and purpose are as follows:

1. The Tax Dispute Settlement Agency is a tax judicial body that has the task of examining and deciding tax disputes in the form of:

a. Appeal against the decision of the competent authority;

b. A lawsuit against the implementation of tax laws and regulations in the field of collection.

2. The decision of the Tax Dispute Settlement Body has the same executive power and legal standing as a court decision that has permanent legal force, with the head of the decision being given the words "For Justice Based on the One Godhead".

3. Filing an appeal or lawsuit to the Tax Dispute Settlement Agency is the last legal remedy for taxpayers and the decision cannot be challenged to the General Court or to the State Administrative Court.

4. With this Law, for the first time, a Tax Dispute Settlement Agency is established which is domiciled in the capital city of the country, and with the power of this Law, a Tax Dispute Settlement Agency with the same level is established in the national capital and in other places whose implementation is regulated by Presidential decree

5. The organizational, administrative and financial development of the Tax Dispute Settlement Agency is carried out by the Ministry of Finance.

6. In order to provide good service and legal certainty to the appeal applicant or plaintiff, the time period for submitting an appeal or lawsuit, as well as examination until the implementation of the decision of the Tax Dispute Settlement Body is determined. If the decision is not taken within the stipulated period, the appeal or lawsuit is granted, whereas if the formal requirements for filing an appeal or lawsuit are not met, the appeal or lawsuit cannot be accepted.

7. One of the formal requirements for filing an appeal is that the amount of tax disputed in the decision being compared must be paid, and if the appeal is granted partially or completely, the appeal applicant is given an interest rate of $2 \%$ (two percent) a month for a maximum of 24 (twenty four) months on overpayment of taxes.

8. One of the requirements for filing a lawsuit is to pay the registration fee.

9. Members of the Tax Dispute Settlement Agency are professionals, namely scholars who have experts in the field of taxation who in carrying out the trial are assisted by the Secretary of the Session.

10. Examinations in a expeditious manner can be carried out by the Assembly or Sole Member.

11. Based on the nature of tax secrecy, the examination by the Tax Dispute Settlement Agency is carried out in a closed session, while the decision is pronounced in a trial open to the public.

12. The decision of the Tax Dispute Settlement Agency can be directly implemented without requiring the decision of the competent authority, unless the law provides otherwise.

\section{RESEARCH METHODOLOGY}

In the context of research regarding seeking justice through the principle of fairness in resolving business entity tax disputes against taxpayers based on Indonesian tax law, the research method used is as follows: the type of research used in this study is descriptive analytical research. problems in society and the procedures that apply in society and certain situations, including about relationships, activities, attitudes, views, and ongoing processes and effects of a phenomenon. Descriptive research aims to make a systematic, factual, and accurate description or description of the facts, nature, and relationships between the phenomena studied (Nazir, 1999:63-64).

In connection with the topic of this research, secondary data will be studied relating to seeking justice through the principle of fairness in the settlement of business entity tax disputes against taxpayers based on Indonesian tax law. While the approach method used in this research is a normative juridical approach, namely setting certain standards or norms for a phenomenon by examining secondary data. Normative legal research is library research, namely research on secondary data (Soemitro, 1990:11). The approach taken is a historical approach which aims to make a systematic and objective reconstruction of the past. In connection with the topic of this research, secondary data will be studied relating to the fairness principle of business entity tax dispute settlement against taxpayers based on Indonesian tax law.

\section{RESULT AND DISCUSSION}

\section{Position of the Tax Court in Indonesia}

The guidance of the Tax Court is in two (2) institutions, namely the Supreme Court and the Ministry of Finance. The Supreme Court provides guidance in the technical-judicial field, while the Ministry of Finance provides guidance in the fields of organization, administration, and finance. This can be found in Article 5 of Law no. 14 of 2002 concerning the Tax Court. The Tax Court is a judicial institution whose main purpose is to uphold justice based on the rule of low principle. It is proper to have 
independence, independence, and impartiality in examining and deciding a case. In practice, many parties doubt the Tax Court because its structure and position are considered not independent.

With the dualism of coaching, it will affect the independence and independence of the Tax Court because in that area it creates a contradiction, namely the Ministry of Finance which is supposed to carry out executive functions but when it participates in supervising and fostering the Tax Court, it automatically takes on the role of a judicial institution. Whereas the executive and judicial institutions should be separate, perform their respective functions, and control or supervise one another (checks and balances).

Judicial power should be independent and independent from the influence of other branches of power. The principle of separation of powers requires judges to work independently or free from the influence of legislative and executive powers. Judges must be independent in examining and deciding the cases they face. Even in understanding and interpreting laws and regulations, judges must also be independent from the opinions of legal experts and the public, including independent from the political will of the legislators (Asshiddiqie, 2016).

The dualism of coaching in the Tax Court is contrary to Article 24 paragraph (1) of the 1945 Constitution of the Republic of Indonesia, that: the power to administer the judiciary is the independent judiciary to uphold law and justice. Also contrary to Article 21 of Law no. 48 of 2009 which states that: The Supreme Court is the highest level of judicial power in Indonesia. The Supreme Court supervises and provides guidance to all judicial institutions, both in the technical-judicial field as well as in the organizational, administrative and financial fields.

Regulation is one manifestation of legal positivism that can create legal certainty. However, the regulation of tax liability in a country, especially in Indonesia, can create the potential for conflict between justice and expediency due to different demands and/or contents in its implementation. So that it is urgently needed an alternative solution that is closely related to the basic deepening of legal values in the form of justice and public benefits applied in the field of taxation that can answer the problem of setting absolute liability for taxpayers as one of the foundations of tax compliance that strengthens the tax system in Indonesia.

The tax court is the first and or last level in terms of examining and deciding on tax disputes as the first and last function court, the examination of everything is only carried out by the tax court. Therefore, against the decision, a lawsuit cannot be filed with the General Court, State Administrative Court or other judicial body, except for the decision in the form of "unacceptable" which concerns the competence of the explanation of Article 33 paragraph 1 of Law Number 14 of 2002. Examples of cases involving happened to the Taxpayer with the initials RW. He is a tax bearer from PT TS which is engaged in wholesale trade (consumer goods) and is registered with KPP (Pratama Tax Office) X which is in arrears of a bill of Rp. 48.25 billion. The Regional Office of the Directorate General of Taxes X and Maluku took RW hostage (gijzeling), which at that time was also deposited in $\mathrm{X}$.

\section{Justice in Exemption of Administrative Sanctions}

As described in the previous discussion, administrative sanctions are sanctions imposed by the state administration based on the authority it has with the aim that citizens obey the rules of administrative law.

The imposition of administrative sanctions originating from government authority can be divided into free authority and bound authority. Bound authority is the authority given to certain state administrations whose norms have been explicitly determined in their basic norms. The state administration cannot take other legal actions, other than the legal actions that have been determined. On the other hand, in a free authority, the administration has the freedom to choose what legal actions can be carried out based on the authority it has.

In this case, the state administration has the freedom to exercise its authority (discretionaire). Freedom to determine the assessment of what legal action will be taken, can be objective or subjective. Freedom of subjective judgment, for example, if the basic rules are formulated with the sentence "can". Words can indicate the existence of free authority owned by the state administration to carry out a certain act based on its own judgment.

In the context of the imposition of administrative sanctions in taxes, it is regulated in Law no. 6 of 1983 as last amended by Law no. 28 of 2007 concerning KUP. Of all the articles that regulate administrative sanctions, whether in the form of fines, increases or interest, the words "can" are not found, as intended in the meaning of free authority, so that the imposition of administrative sanctions in the tax law is categorized as binding authority. However, Article 36 paragraph (1) of the 1983 KUP Law also gives free authority to the Director General of Taxes to reduce or eliminate administrative sanctions, if the administrative sanctions are imposed due to the taxpayer's negligence. This article reads as follows:

"The Director General of Taxes may reduce or abolish administrative sanctions in the form of interest, fines and increases owed according to the provisions of the tax laws and regulations in the event that the sanctions are imposed due to the taxpayer's negligence or not because of his fault".

The same provision is also found in Article 36 paragraph (1) of the 2007 KUP Law. Based on the provisions of Article 36 paragraph (1) above, the reduction or elimination of administrative sanctions can only be carried out if the administrative sanctions imposed are not caused by the actions of the taxpayer who done intentionally.

From the sound of the provisions above, the authority to abolish administrative sanctions as regulated in Article 36 paragraph (1) in addition to containing free authority, also contains bound authority. Bound authority is indicated by the condition that it is not done intentionally (by mistake). The extent to which the state administration (fiskus) has the authority to waive administrative sanctions will be related to the discretionary issue of the state administration, namely a policy based on the freedom to act or make decisions on its own initiative in order to resolve various difficult problems that require proper handling. Simandjuntak , R. (2014). 
Arguments or reasons in relation to the abolition of administrative fines are related to state revenues. The increase in state revenues in the future will make it easier to achieve public welfare by financing the public interest. The imposition of administrative fines on taxes that were not or underpaid in previous years will cause the tax debt to be paid to increase so that it will lead to rejection from the taxpayer. By using the collection expiration time limit of 5 years (Article 22 KUP 1983), taxpayers must pay administrative sanctions during that time and this will burden the taxpayer. Therefore, the cumulative imposition of administrative sanctions for several years is a less efficient and effective measure for state revenues. The explanation of the article above states that the abolition or reduction in question is based on the element of justice.

It must be admitted that there is no objective measure of justice or injustice, if the assessment is based on or determined by the culture of the community that he believes in, what emerges is subjective justice. In legal science what emerges are general principles in the formulation of laws such as equality in legal standing, balance of rights and obligations, the right to defend/protect interests and so on.

In tax amnesty, justice places more emphasis on legal justice in the sense of justice according to the law, by releasing the authority of state administration (fiskus) to impose administrative sanctions. Justice frees administrative sanctions more emphasis on greater interests than just justice for individual interests.

The authority to collect taxes, including exempting, excluding or relinquishing the right to collect taxes, is the power that exists in the state as a manifestation of the sovereignty of the state. Thus the magnitude of the power that exists in the state, the law can also be created by the state, through the state administration Pudyatmoko, Y. S. (2013).

Obstacles in the Tax Dispute Settlement Process The current Tax Court is domiciled in the State Capital (see Article 3 of Law No. 14 of 2002). Thus, the Tax Court will always be in Jakarta provided that the capital city of the country does not move. According to the author, this is not in accordance with the principles of justice, namely the principle of simple, fast, and low-cost case settlement. This is considering that the potential for tax disputes is very large because the number of taxpayers is increasing and spread throughout Indonesia. Besides the increasing number of taxpayers from year to year, the range of Indonesia's territory from Sabang to Merauke, from Miangas to Rote Island is very far from Jakarta. Like the taxpayer in X, for example, if the person concerned is not satisfied with the Tax Assessment Letter (SKP) or the Tax Collection Letter (STP) issued by the Tax Service Office in X, of course the distance between X and Jakarta is very far. Taxpayers will pay a fairly large fee both for transportation costs, accommodation and it takes longer than if the Tax Court is in the area where the taxpayer is located, at least in the provincial capital (Pudyatmoko, 2009). Indeed, the Tax Court Law does not require the presence of the plaintiff or appeal applicant to be present at the sessions at the Tax Court, but if the plaintiff or appeal applicant is not present at the trial it will weaken himself because the opposing party in this case the tax authorities or tax officials will freely answer questions from the judge, freely explaining the facts according to his version without any objection from the plaintiff or the appellant.

In practice, the trial in the Tax Court can take up to 8 (eight) times, even for more complicated cases it may be more than 8 (eight) times. It can be calculated how much money must be spent by taxpayers residing in Abepura or taxpayers residing in the outer regions of Indonesia. Starting from the cost of round-trip transportation from Abepura to Jakarta, the cost of staying and other accommodation while in Jakarta. Of course, taxpayers will spend quite a lot of money. Another obstacle in the tax dispute resolution process at the Tax Court is the provision regarding administrative sanctions in the form of a fine of $98 \%$ (one hundred percent) if the taxpayer's appeal is rejected or partially granted. This provision is not regulated in Law No. 14 of 2002 but is regulated in Article 27 paragraph (5d) of Law No. 28 of 2007 concerning KUP.

If we examine further that the application of fines at the appeal level is contrary to the preamble of letter c of the Tax Court Law which states that tax disputes require a just settlement with fast, cheap, and simple procedures and processes and are also not in accordance with the principles of The implementation of judicial power, namely the principle of justice, is carried out in a simple, fast, and low-cost manner. The imposition of these fines causes the appeal process to be no longer cheap. Even though filing objections and appeals is the right of all taxpayers who want to get justice, they are actually afraid and worried about the threat called administrative sanctions in the form of fines. Taxpayers will think and calculate before they decide to resolve tax disputes through an appeal process at the Tax Court.

\section{CONCLUSIONS AND SUGGESTIONS \\ Conclusions}

1. Justice in the model or form of tax amnesty cannot be answered by the theory of tax burden justice, in the form of horizontal and vertical justice. The tax amnesty policy cannot be separated from the purpose of tax collection itself, namely for the general welfare, beyond individual taxpayers. In accordance with the concept of a state of law, tax amnesty as a legal product in the field of taxation must be able to reflect the purpose of the law itself, namely justice, certainty and benefits for the whole community. Suggestions that can be given are the use of the tax amnesty model in the form of exemption from the obligation to pay taxes that were previously unpaid and exemption from the imposition of sanctions must be followed by strict law enforcement after the amnesty by prioritizing administrative law instruments Therefore, it is necessary to make changes to UUKUP.

2. Self Assessment System is a tax collection system that gives authority, trust, and responsibility to taxpayers to calculate, calculate, pay and report themselves the amount of tax that must be paid. Tax dispute resolution procedures can only be resolved through the tax court, considering that the tax court is an instrument that can be used as a means for justice seekers to obtain justice, namely to protect the interests of taxpayers. Considerations made in tax collection in principle must pay attention to fairness and validity in its implementation. To meet the demands for justice and validity, it is necessary to pay attention to the principle of tax collection, namely the principle of equality which emphasizes the importance of balance based on the ability of each tax subject. The interpretation of the objection provisions, the appeal not delaying the payment 
of taxes and the implementation of the collection of tax debts with the obligation to pay off the tax debt in the amount stated in the SKP raises problems when it is associated with the requirements for filing an objection and the appeal itself.

3. Indonesia as a legal state is characterized by a welfare state that has the will to create justice for all Indonesian people. In a modern welfare state, the task of the government in carrying out the public interest is very broad and sometimes violates the rights of taxpayers in collecting taxes. Tax dispute is a dispute that arises in the field of taxation between the taxpayer and the tax authorities as a result of the issuance of a decision that can be appealed or a lawsuit to the tax court based on tax laws and regulations. In resolving tax disputes, taxpayers have the right to file various legal remedies based on the provisions of the law. Legal efforts outside the court can be carried out because legal remedies outside the tax court or tax court in the mediation section of the Administrative Court, in the form of rights that may be used to correct legal actions that have occurred. carried out by the taxpayer himself or a legal action that has been carried out by the tax authorities,

\section{Suggestions} thus the taxpayer's rights as determined in the tax law are legal remedies outside the tax court.

1. The implementation of tax payments and the implementation of tax debt collection with the obligation to pay off the amount of tax debt contained in the SKP creates problems when it is associated with the requirements for filing objections and appeals for taxpayers to pay $60 \%$ of the total tax payable. In this regard, the provision of "not delaying the payment of taxes" in the appeal is defined as the obligation to pay tax only in the amount of $60 \%$ of the amount owed in the SKP. It is hoped that the government can make changes to the regulation on the payment of $60 \%$ of the total tax payable for the taxpayer's objection or appeal, because being found guilty must be based on the judge's decision so that the taxpayer's sense of justice is not fulfilled.

2. There are two models of tax dispute resolution, namely settlement through administrative efforts and through a pure judicial institution, namely the tax court, it is hoped that the tax court can be included in the PTUN realm because what is disputed is the SKP which is an administrative decision by the TUN Official which is the object of the TUN lawsuit. Settlement through administrative efforts is a dispute resolution where the settlement still includes litigants, namely the tax authorities (objection process) and dispute resolution and is intended to make it easier for justice seekers to obtain justice and obtain legal protection both for the administration itself and for taxpayers, as well as in tax courts under the PTUN provided mediation space for taxpayers, tax authorities, and mediators to resolve tax disputes through mediation.

\section{REFERENCES}

Abduh, A. (2019). Settlement of Tax Disputes Through Objection Agencies. Eksekusi, 1(2).

Asshiddiqie, J. (2016). Pengantar Ilmu Hukum Tata Negara. Jakarta: PT. Rajagrafindo Persada.

Barda Nawawi Arief, 1994, Legislative Policy in Combating Crimes with Imprisonment, Badan Penerbit Universitas Diponogoro, Semarang,

Hadi, H. (2017). Reformulation of Tax Dispute Settlement Arrangements in Indonesia (Doctoral Dissertation, Universitas Brawijaya).

Ispriyarso, B. (2018). Legal Efforts in Tax Disputes. Administrative Law \& Governance Journal, 1(1), 9-14.

Maheswara, R. H. (2020). Tax Court Principles in Tax Dispute Resolution (Doctoral Dissertation, Universitas Airlangga).

Marlina Peradilan Pidana Anak di Indonesia, 2012 Cet ke II,

Marzuki Peter Mahmud, 2006, Penelitian Hukum, Kencana, Jakarta, hal. 182

Perangin-Angin, V. A. B. Upaya Hukum Penyelesaian Sengketa Pajak.

Pudyatmoko, Y. S. (2013). Pengadilan Dan Penyelesaian Sengketa Di Bidang Pajak. Gramedia Pustaka Utama.

Refiko Aditama M. Nasir Djamil, 2013, Anak Bukan Untuk Dihukum, Sinar Grafika, Jakarta, Rika Saraswati dalam Penanganan Masalah yang berkaitan dengan Undang-Undang Perlindungan Anak (UU No 23 Tahun 2002)

Simandjuntak, R. (2014). Tax Dispute Settlement Arrangements (Viewed From the Aspect of Justice). Kumpulan Jurnal Mahasiswa Fakultas Hukum, 1(1).

Soryono Soekanto dan Sri Mamuji, Penelitian Hukum Normatif Suatu Tinjauan Singkat 2012 PT Grafindo Persada Jakarta Cet ke XIV. Lilik Mulyadi, Wajah Sisten Peradilan Pidana Anak Indonesia, 2014 PT Alumni.

Sulastini, N. M. I., Widiati, I. A. P., \& Sutama, I. N. (2021). Penyelesaian Sengketa Pajak Penghasilan (PPH) Pasal 21 Melalui Pengadilan Pajak. Jurnal Konstruksi Hukum, 2(1), 180-185.

Supriyadi, S., Setiawan, B., \& Bintang, R. M. (2018). Evaluation of Objection Institutions in Fair Tax Dispute Resolution at the Directorate General of Taxes. Jurnal Pajak Indonesia (Indonesian Tax Journal), 2(2), 6-19. 
Undang Penghapusan Kekerasan Dalam rumah Tangga (UU No 23 Tahun 2004) dan Undang-undang Pemberantasan Tindak Pidana Perdagangan Orang (UU No. 21 Tahun 2007) oleh Aparat Penegak

Zaidan, Menuju Pembaharuan Hukum Pidana, Sinar Grafika,2015 , Cetakan I Barda Nawawie Arief, Bunga Rampai Kebijakan Hukum Pidana, 1996 PT Citra Aditya Bakti, 